\title{
HYBRIDIZATION AND MALE PARENTAL INVESTMENT IN BIRDS ${ }^{1}$
}

\author{
Raymond Pierotti and Cynthia A. AnNett \\ Department of Systematics and Ecology, University of Kansas, \\ Lawrence, $\mathrm{KS}$ 66045-2106
}

\begin{abstract}
Hybridization within genera occurs more frequently in avian families and subfamilies where there is considerable male parental investment, less frequently in families with moderate levels of male parental investment, and rarely in lineages where males contribute only genetic material to their offspring. In addition, genera that show considerable male parental investment are typically less speciose than genera where there is reduced male parental investment. Species showing high levels of male parental investment, however, typically have more subspecies, indicating that local adaptation evolves in these groups, but reproductive isolation does not evolve. Some hybrid matings appear to involve females of one species showing an apparent preference for mating with larger or dominant males, even if these males are heterospecific (e.g., black and mallard ducks). Similar patterns occur in fishes, amphibians, and mammals, the other three vertebrate lineages that show extensive parental care. Hybridization in birds may be an evolutionary mechanism that allows increased genetic diversity and adaptability under changing environmental conditions, particularly environments disturbed by humans. It is also possible that new forms (incipient species) may arise through hybridization that are better adapted to disturbed environments than either parental species.
\end{abstract}

Key words: Hybridization; parental investment; speciation; adaptation.

\section{INTRODUCTION}

Understanding the stability of naturally occurring hybrid zones in birds (Blair 1951, Short 1969) is problematical for two reasons. First, hybrid zones should be ephemeral because selection against hybrid offspring should lead to evolution of reproductive isolating mechanisms (Blair 1951, Mayr 1963). Alternatively, if hybrid offspring are selectively favored, i.e., hybrid vigor, introgression should occur, leading to disappearance of the hybrid zone (Dobzhansky 1940, Sibley 1957, Mayr 1963, Barton 1979). Second, avian hybrid zones often occur in ecotones, including areas of disturbed and fragmented habitat (Rising 1983, Moore 1977, Panov 1989). In ecotones and disturbed habitats hybridization is thought to be the result of either (a) low population densities or (b) ecologically distinct forms coming into contact in marginal habitat (Barton and Hewitt 1985, Harrison 1991). In such cases, hybridization is assumed to be the result of non-adaptive or even maladaptive behavior.

In recent years, however, it has been argued and demonstrated that hybridization in birds may not always be maladaptive (Cade 1983; Moore and Buchanan 1985; Grant and Grant 1989, 1993.

1 Received 18 February 1993. Accepted 22 February
1992). In this paper, we suggest that the pattern of occurrence of naturally occurring intrageneric hybrids in birds is non-random with regard to mating system, and may in fact result from adaptive behavior with evolutionary consequences.

We use as our starting point the "hybrid superiority" hypothesis of Moore (1977, Moore and Buchanan 1985). Moore suggested that hybrids may be selectively equivalent, or possibly superior, to parental types in the habitats where they occur. Numerous studies of both animals and plants have provided support for the idea that hybrids may be, at the least, selectively equivalent to their parental species in certain habitats (Anderson and Stebbins 1954, Rattenbury 1962, Bullini and Nascetti 1990, Whitham et al. 1991, Grant and Grant 1992).

Our intent is to evaluate Moore's hypothesis within the context of mate-choice in birds. In all birds, hybridization is the consequence of an active choice of a mating partner (Wilson and Hedrick 1982). Although choice of a heterospecific mate is typically regarded as an error or a failure of an isolating or specific mate recognition mechanism (Mayr 1963), this need not always be the case. We argue that in certain circumstances, there may be benefits to such "erroneous" choices.

To develop this argument, we consider a possibility implicit in Moore's hypothesis (1977), that if hybrids are at least selectively equivalent 
to parental types in some circumstances, there is no fitness cost against such matings. If instead, females choose a heterospecific male that provides adaptive benefits, e.g., higher quality male parental care, hybridization could be selectively favored. This is likely to lead to formation of stable hybrid zones rather than introgression if hybrids are equivalent or superior to parental types within the habitats comprising the zone (e.g., ecotones or disturbed habitats) but inferior to parental types in other habitats.

Mate choice may work through two alternative mechanisms. First, choice may be based on physical traits, such as color or size, for which there is an initial preference by the opposite sex and sufficient additive genetic variation. Such choices are considered "arbitrary" (Kodric-Brown 1990). Since models of the evolution of such traits (e.g., Lande 1981) focus primarily on the impact of the trait on male reproductive success, arbitrary mate choice, which is found in polygynous or promiscuous mating systems, could lead to a reduction in female fitness if the trait under selection lowered overall offspring viability.

Alternatively, females will gain adaptive benefits from males when choice can be based on the traits that contribute directly to the immediate fitness (reproductive success) of the individual making the choice ("adaptive" choice, Kodric-Brown 1990). In birds such choices might employ traits that are likely to serve as indicators of "parental quality" (quality of territory held, quality of food provided by the prospective mate; Nisbet 1973, Pierotti 1981, Morris 1986). In most monogamous birds genetic and parental quality are not mutually exclusive; a superior mate probably indicates its overall quality through provision of food or territory (Nisbet 1973, Pierotti 1987b).

It has been argued that mate choice based upon arbitrary criteria could lead to speciation through selection for success in intraspecific social competition (intrasexual competition; Lande 1981, 1982; West-Eberhard 1983). The complement of this argument is that if female choice was based on traits involved in male investment, fitness benefits to females from male investment could counteract the selection typically assumed to occur against hybridization, and prevent the evolution of post-zygotic isolating mechanisms. This could reduce the rate of species formation in groups where parental care is important in mate selection.
In some species females might prefer heterospecific males that were superior at territory acquisition, provision of food, guarding of mate and offspring, or all of the above (see Wilson and Hedrick 1982 for a variation on this argument). This situation might apply especially where two closely related species differ primarily in size and each species shows a slight degree of sexual dimorphism, e.g., Larus gulls (see below). Where two such species breed sympatrically, small males of the larger species may not be chosen by conspecific females or able to compete with conspecific males for resources. These males would, however, be able to dominate males of the smaller species, and they might therefore be more attractive to large females of the smaller species, who would also have more difficulty in obtaining a conspecific mate. Similar situations might occur whenever conspecific mates are hard to find (Wilson and Hedrick 1982).

Male parental investment at levels occurring in most monogamous birds (Kendeigh 1952, Verner and Willson 1969, Pierotti 1981, Silver et al. 1985) should lead to mate choice based on traits that predict male investment. Consequences of this female choice could be: (1) reduced development or nondevelopment of isolating mechanisms or specific mate recognition systems, (2) greater rates of hybridization, and (3) reduced numbers of species per genus. Furthermore, because of local adaptation without evolution of reproductive isolation, lineages with extensive male parental investment will (4) show more subspecies per species than lineages with little or no male parental investment, polygyny, strong sexual dimorphism, and well developed reproductive isolation.

\section{RESULTS \\ MALE PARENTAL INVESTMENT AND HYBRIDIZATION}

Birds show the highest occurrence of monogamy of any group of animals, with more than $90 \%$ of species being primarily or exclusively monogamous (Lack 1968, Silver et al. 1985). All monogamous birds have some male parental care. Hybridization is also more common in birds than in any other group of vertebrates (Mayr 1963, Short 1969, Rising 1983, Morrison and Hardy 1983, Pierotti 1987a, Panov 1989). The frequency of intrageneric hybridization in birds could be considered as weak support for the idea 
TABLE 1. Distribution of the three major categories of mating system and sexual dimorphism among families of passerines and non-passerines ( $n=$ number of families or subfamilies).

\begin{tabular}{lccc}
\hline \hline & $\begin{array}{c}\text { Monogamous Monogamous } \\
\text { and } \\
\text { monomorphic }\end{array}$ & $\begin{array}{c}\text { Polygynous } \\
\text { and } \\
\text { dimorphic }\end{array}$ & $\begin{array}{c}\text { dimorphic } \\
\text { Non-passerines }\end{array}$ \\
Passerines & 34 & 8 & 4 \\
\hline
\end{tabular}

that there is a relationship between male parental investment and hybridization.

Naturally occurring hybridization in birds was surveyed using Panov (1989) as our primary source (see Appendix). Other sources were included for specific families, subfamilies, and genera when they contained information not included by Panov. All families or subfamilies of birds from which intrageneric hybrids were observed were divided into three categories: (1) monogamous and sexually monomorphic, (2) monogamous and sexually dimorphic (sexual dimorphism was based upon large differences in size or plumage color), or (3) polygynous and dimorphic. Sexual dimorphism was based upon large differences in size or plumage color, so that slight differences in size, as occurs in Larus gulls (Pierotti 1981), or slight differences in plumage color, as occurs in woodpeckers, were not considered as dimorphism for our purposes. Polyandrous families were considered to be monogamous and sexually dimorphic, since we examine the relationship from the perspective of female choice on male parental care.

We employed the family or subfamily as the unit of analysis because this level represents a compromise between the species level, where missing data pose problems, and the order, where heterogeneity could obscure relationships (Lack 1968, Silver et al. 1985). In a few cases where a family showed heterogeneity with regard to mating system and dimorphism, we treated each category as separate cases for analysis. Review yielded 90 families or subfamilies in which intrageneric hybridization has been observed (see Appendix and Panov 1989 for details).

The overall distribution among mating types can be seen for both passerines and non-passerines in Table 1. Although there is no significant heterogeneity, families in which species are monogamous and sexually dimorphic are more common than expected among passerines, and
TABLE 2. Frequency of hybridization in relation to mating system and sexual dimorphism in avian families (data from Panov 1989). Differences among categories are significant at $P<0.01$ by Kruskal-Wallis (on transformed data). For purposes of analysis polyandrous species were considered to be monogamous and dimorphic.

\begin{tabular}{lcc}
\hline \hline & $\begin{array}{c}\text { Percent } \\
\text { species } \\
\text { reported to } \\
\text { hybridize/ } \\
\text { Family } \\
\bar{x}\end{array}$ \\
$\begin{array}{c}\text { Mating system } \\
\text { Dimorphism } \\
(n=\# \text { families })\end{array}$ & $\begin{array}{c}\text { Family } \\
\bar{x}\end{array}$ & 34 \\
\hline $\begin{array}{l}\text { Monogamous } \\
\text { Monomorphic }(n=55)\end{array}$ & 53.5 & 17 \\
$\begin{array}{c}\text { Monogamous } \\
\text { Dimorphic }(n=24)\end{array}$ & 108.0 & 9 \\
$\begin{array}{c}\text { Polygynous } \\
\text { Dimorphic }(n=9)\end{array}$ & 95.0 & \\
\hline
\end{tabular}

families in which species are monogamous and monomorphic are more common among nonpasserines.

Examination of the frequency of hybrids within families (calculated by dividing the number of hybrid crosses recorded by the total number of species for each family or subfamily) yielded a significant pattern. Families where all species are monogamous and monomorphic, which have consistently higher levels of male parental care (Kendeigh 1952, Lack 1968, Verner and Willson 1969, Silver et al. 1985), show twice the frequency of hybrids compared with families in which species are monogamous and dimorphic, and nearly four times the frequency of hybrids compared with families where species are polygynous and dimorphic (Table 2; differences significant among categories at 0.01 level by Kruskal-Wallis test on logarithmically transformed frequencies). Families that are monomorphic also have significantly fewer species/family $(P<0.01$ by Kruskal-Wallis), which suggests that reproductive isolation does not evolve as readily in such families (see below).

Further relevant evidence is that as a consequence of extensive interbreeding, several "species" of monomorphic and monogamous birds have been reclassified as subspecies and combined into single species. These include several passerines: (1) Dark-eyed Juncos (Junco hyemalis; formerly four species: Short 1969), (2) Common Grackle (Quiscalus quiscala; formerly two species: Short 1969), and (3) Asiatic Crows (Corvus corone; formerly three species: Vaurie 1954, Picozzi 1976). Also included are a few 
woodpeckers: (1) Common Flickers (Colaptes auratus; formerly three species: Short 1965), and (2) Yellow-bellied and Red-breasted Sapsuckers (Sphyrapicus varius; formerly three species: Howell 1952).

Some monogamous and dimorphic passerine species also have been lumped because of extensive interbreeding. These include Northern Oriole (Icterus galbula; formerly two species: Rising 1970), Rufous-sided Towhees (Pipilo erythropthalmus; formerly three to four species: Sibley and West 1958, 1959), and Yellow-rumped Warblers (Dendroica coronata; formerly two species: Hubbard 1969, Barrowclough 1980). In these dimorphic species, males and females differ primarily in plumage, rather than size, and all show extensive male parental investment (Verner and Willson 1969).

Some non-passerines that are monomorphic in plumage but slightly dimorphic in size also show extensive hybridization. Several species of large white-headed gulls, genus Larus, hybridize freely where they occur sympatrically (Ingolfsson 1987, Pierotti 1987a, Bell 1992). In gulls, males are $20-30 \%$ larger than females (Pierotti 1981), and selection occurs against small males and large females (Monaghan and Metcalfe 1986). Male gulls prefer small females and female gulls prefer large males (authors' unpubl. data). Although it has been suggested that the contrasting colors of the fleshly eye-ring and the iris act as an isolating mechanism in this group (Smith 1966), there is little evidence that this trait serves as an effective isolating mechanism between any species pairs (Pierotti 1987a).

One species, the Glaucous-winged Gull, $L$. glaucescens, hybridizes with Western Gulls, $L$. occidentalis, from the Columbia River north to the Straight of Juan de Fuca; with the Herring Gull, $L$. argentatus, in southeastern Alaska; and with the Glaucous Gull, L. hyperboreus, in the Bering Sea (Hoffman et al. 1978, Patten 1980, Pierotti 1987a, Bell 1992). In some colonies where these species occur sympatrically more than $40 \%$ of the pairs are mixed species or hybrid pairs (Hoffman et al. 1978, Bell 1992).

Reticulate evolution may be occurring in Larus gulls, with new "species" resulting from interbreeding. In central Asia, the coastal Siberian form Larus (argentatus) taimyrensis appears to be a stabilized hybrid of $L$. (fuscus/argentatus) heuglini and L. (argentatus) vegae, since it shows characteristics of both "parental" forms, shows high interpopulation variability, and occupies a range intermediate between the two "parental" forms (Panov 1989). In addition, L. taimyrensis appears to interbreed with $L$. (argentatus) cachinnans in Western Siberia and Kazakstan to produce yet another form $L$. barabensis (Panov 1989). The taxonomy of this group is in flux, and further study, including molecular systematics, will be necessary to establish the relationships within this group.

With regard to our predictions, gulls show extensive male parental investment, with males establishing and defending the breeding territory, feeding the female ("courtship" or mate feeding) for two to three weeks prior to egg-laying, sharing in incubation duties, and feeding and defending both the mate and offspring (Pierotti 1981, 1987b). Male gulls typically deliver significantly more food to offspring than do females, and aside from egg formation, probably expend far more energy during reproduction than do their mates (Pierotti 1981, 1987b, Burger 1981). Larger males are better at establishing and holding large territories, and at bringing back large amounts of food, therefore, females of smaller species of gulls (e.g., Western, Herring) looking for a superior male parent might prefer males of larger species, e.g., Glaucous-winged Gulls. Mixed-species Glaucous-winged/Western Gull pairs have higher breeding success than either single species pair (Hoffman et al. 1978). In this group, hybrids appear to be readily accepted as mates by both parental "species" (Patten 1980, authors' unpubl. observ.), so there is little short-term selection against either interbreeding or hybrid offspring.

A related situation prevails in the genus Anas, where female Black (A. rubripes) and Mexican (A. diazi) Ducks actively prefer male Mallards (A. platyrhynchos) to male conspecifics (Sibley 1957, Bellrose 1980, Brodsky and Weatherhead 1984, Brodsky et al. 1988). In these species, male Mallard differ greatly from females in coloration, whereas male Black and Mexican Ducks are similar to females in appearance. As Mallard have extended their range, they have interbred so frequently with these other species that the Mexican duck has been reclassified to be conspecific with the Mallard, and the Black Duck is considered endangered as a species (Bellrose 1980). This situation may have resulted because forced copulation by several males is an important cause of mortality in female ducks (McKinney 1986). Fe- 
TABLE 3. Comparison of monomorphic and dimorphic North American passerine birds in the distribution of various forms of male parental care (data from Verner and Willson 1969). Each category of male parental role differs in occurrence between sexually monomorphic and dimorphic groups with probability $P<0.05$ by Chi square test.

\begin{tabular}{lrrrrr}
\hline \hline \multirow{2}{*}{$\begin{array}{c}\text { Male parental } \\
\text { roles }\end{array}$} & \multicolumn{2}{c}{ Monomorphic } & & \multicolumn{2}{c}{ Dimorphic } \\
\cline { 2 - 3 } \cline { 5 - 6 } \cline { 5 - 6 } Nest building & \multicolumn{1}{c}{ Yes } & No & & Yes & No \\
\hline Incubate eggs & $94 \%$ & $6 \%$ & & $71 \%$ & $29 \%$ \\
Feed nestlings & $100 \%$ & $0 \%$ & & $80 \%$ & $20 \%$ \\
\hline
\end{tabular}

males can avoid this kind of harassment by pairing with a male who guards them from harassment. Brightly colored male Mallards are much more effective at guarding a female than the less conspicuous males of Black and Mexican Ducks (Brodsky and Weatherhead 1984, McKinney 1986). This allows females paired to male Mallards to spend more time foraging, and the dominant male Mallards may also secure superior foraging sites (McKinney 1986, Brodsky et al. 1988). Thus, survival rates and breeding success of female Black and Mexican Ducks probably increases as a result of pairing with male Mallard.

In both gulls and ducks some females that mate with heterospecific males have increased survival rates or reproductive success relative to females of their species that mate with conspecifics. Similarly, mixed species pairs of Geospiza (a monogamous, monomorphic genus of Passerine) show higher fitness (long-term breeding success) than pure pairs of either parental species (Grant and Grant 1992). Such increases in fitness could lead to an evolved preference for males of another species. Over evolutionary time, this would prevent evolution of isolating mechanisms, and could lead to reduced rates of speciation in these lineages. Additionally, this could lead to increased numbers of subspecies as populations adapted to local conditions.

\section{MALE PARENTAL INVESTMENT AND SPECIATION IN NORTH AMERICAN BIRDS}

If we examine the relationship between male parental investment and speciation, there is strong evidence for our prediction that forms with greater male parental investment are less speciose, but have more subspecies/species. For example, geese, which are monogamous and monomorphic with extensive male parental investment, form many distinct subspecies, but relatively few species, whereas the dimorphic ducks which have no male parental care show the opposite trend (Mayr 1942, p. 241-242). In North America, there are three genera of geese (Branta, Anser, Chen) with only one to two species/genus but numerous subspecies/species. In contrast, the duck genera Anas and Aythya contain 10 and five species respectively (Robbins et al. 1983).

Similarly, dividing North American passerines into sexually dimorphic and sexually monomorphic forms yields roughly $60 \%$ monomorphic and 40\% dimorphic species (Lacy 1985). Monomorphic forms typically show a higher level of male parental investment than dimorphic species, since monomorphic male passerines are more likely to: (a) participate in nest-building, (b) share in incubation, and (c) feed nestlings than males of dimorphic passerine species (Table 3; Kendeigh 1952, Lack 1968, Verner and Willson 1969, Silver et al. 1985).

Monomorphic species have significantly more subspecies per species than dimorphic species (Table 4, and Lacy 1985). Comparing the distributions of subspecies per species, $50 \%$ (51) of dimorphic species are monotypic compared with only 33\% (47) of monomorphic species (Table 4). In contrast, $48 \%$ (67) of monomorphic species have three or more subspecies, compared with only $28 \%$ (29) of dimorphic species (19\% (27) of monomorphic and $22 \%$ (23) of dimorphic species have two subspecies each). Overall, the difference between the two distributions is significant (Chi-square test, $\chi^{2}=9.65,0.001<P<0.01$ ).

Although subspecies can be considered incipient species (Mayr 1942, p. 155), the occurrence of numerous subspecies indicates that a species is differentiating and adapting to local conditions without evolving mechanisms that would lead to species formation (Zink and Remsen 1986). As a result, interbreeding among parapatric subspecies is likely to be frequent.

\section{DISCUSSION}

There appears to be a relationship between incidence of male parental investment and hybridization in birds. This supports the idea that, in some cases, females of one species may prefer mates of another species if heterospecific males give indications that they are superior parents (e.g., provide better or larger territories, provi- 
sion mates or chicks at a faster rate or with larger prey items). When heterospecific males are superior parents, as may occur in gulls (Hoffman et al. 1978), or are superior at guarding females from harassment (e.g., Mallards; Brodsky et al. 1988), reproductive success of females preferring heterospecific males could exceed that of females preferring conspecific males.

Lineages where this pattern is common may fail to evolve effective reproductive isolating mechanisms or specific mate recognition systems. Consequently, some lineages do not subdivide into biological species, but form numerous subspecies as they invade different habitats. In other cases, interbreeding species will be recognized as separate species, but still interbreed with close congeners to varying degrees.

Both situations will maintain diversity within species gene pools (Grant 1963, Arnold 1992). Subspecies will show adaptations to local conditions that result in distinct phenotypes that can be consistently distinguished from each other (Zink and Remsen 1986), but still retain the capacity to interbreed, whereas interbreeding between recognized species will raise the level of genetic variation above the level for unhybridized populations (Grant 1963, p. 182). In addition, hybridization may serve to introduce genetic variation (heterozygosity) into species that have experienced genetic bottlenecks, either as a result of reduced population size or strong selective events (Grant and Grant 1989).

One likely characteristic of lineages that interbreed freely is, because they have numerous subspecies, they could occupy large geographic ranges. This appears to be true for most birds that show both extensive male parental investment and frequent hybridization. In North America, Common Flickers, Sapsuckers, Dark-eyed Juncos, Yellow-rumped Warblers, Rufous-sided Towhees, Northern Orioles, and Mallards all occupy ranges that extend from northern boreal forests well into Mexico (Robbins et al. 1983). In Eurasia, the Corvus corone group and the House Sparrow group occur throughout the entire continent north of the tropics. The "Herring Gull group" interbreeds freely throughout the northern hemisphere north of the tropics (Pierotti 1987a).

Some forms are widespread without having been split into separate species, e.g., Canada Geese (Branta canadensis). Such species have evolved numerous subspecies that are readily identifi-
TABLE 4. The mean, standard deviation, and distribution of the number of subspecies per species from sexually monomorphic and dimorphic North American Passerine birds (Data from Lacy 1985).

\begin{tabular}{|c|c|c|c|}
\hline & Monomorphic & & rphic \\
\hline \multirow[t]{3}{*}{$\begin{array}{l}\text { Number of named } \\
\text { subspecies/species }\end{array}$} & $\begin{array}{c}3.77 \pm 0.37^{*} \\
(n=141)\end{array}$ & & $\begin{array}{l}0.26 \\
103)\end{array}$ \\
\hline & \multicolumn{3}{|c|}{ Number of subspecies/species* } \\
\hline & 1 & 2 & $3+$ \\
\hline \multirow{2}{*}{$\begin{array}{l}\text { Dimorphic species } \\
\text { Monomorphic species }\end{array}$} & 51 & 23 & 29 \\
\hline & 47 & 27 & 67 \\
\hline
\end{tabular}

* Difference between distributions significant. Chi-square test $=9.65$; $0.05<P<0.01 ; \mathrm{df}=2$.

able. This implies that despite selective pressures that lead to geographical variation (see review in Zink and Remsen 1986), there also appears to be sufficient selective pressure to counter the evolution of mechanisms that promote reproductive isolation. Possible pressures are that: (1) under certain circumstances, females may achieve greater fitness by mating with males from different populations that provide superior parental care (Wilson and Hedrick 1982), and (2) new genetic material may be mixed into the gene pool that allows descendants to prosper in a perturbed or changing environment (Grant and Grant 1989, 1992).

Evidence that supports this line of thinking is that many of these hybridizing lineages or species have been able to persist, and even in some circumstances to expand ranges and prosper in the face of major habitat alteration by humans (see Bullini and Nascetti 1990 for a similar argument for insects). Among species that hybridize regularly are gulls, crows, and Mallards, all of which are avian "weed" species in North America. This interbreeding between species may increase diversity within gene pools and could produce heterosis (hybrid vigor) in some forms (Manwell et al. 1962, 1963; Grant and Grant 1989, 1992; Arnold 1992).

Population declines resulting from both persecution and habitat destruction could lead to extinction or great reduction in genetic diversity in lineages where hybridization is prevented by strong isolating mechanisms. In species which are capable of hybridization with congeners, however, an alternative path is available. Interbreeding could allow the maintenance of viable population size or the restoration of genetic di- 
versity (Grant and Grant 1989, 1992; Arnold 1992). Such hybridization could conceivably result in one or both species becoming technically "extinct." We briefly explore this issue, because of its important implications for conservation.

Hybridization can lead to an increase in genetic diversity and possibly to the production of forms better adapted to new or altered environments. This idea is long-standing in the botanical literature (Anderson 1948, Anderson and Stebbins 1954, Rattenbury 1962, Arnold 1992), where it has been argued that most, or all, detectable variation in plant species is the result of introgression (Anderson 1953; p. 300, Grant 1963; p. 183-184). In birds, Grant and Grant (1989, 1992) argue that hybridization restores genetic variation in the Large Galapagos Ground Finch, Geospiza fortis, after variation has been reduced by strong selective events.

Introgression may also be responsible for the production of new "species" in both animals and plants, including the widespread saltmarsh grass, Spartina anglica (Gray et al. 1991), grasshoppers and irises (Arnold 1992), phasmid insects (Bullini and Nascetti 1990), red wolves, Canis rufus (Wayne and Jenks 1991), the Italian House Sparrow, Passer italiae (Johnston 1969), and Central Asian Larus gulls (Panov 1989). It is possible, therefore, that numerous avian lineages, e.g., Larus, Anas, Geospiza, Passer, may be undergoing extensive evolutionary changes through the introduction of new genetic material by hybridization.

Finally, it is notable that human activities have left few habitats undisturbed, and have created ecotones and edges in many areas that were once unbroken single habitats. This creates situations under which hybridization should be expected (Moore 1977, Harrison 1991, Whitham et al. 1991). Consequently, we should expect hybridization to become more frequent. This is especially so if, as we argue, hybrid matings may yield higher reproductive success than same species pairings in ecotones and disturbed habitats.

Similarly, that some threatened species may interbreed with other, less threatened, species should not affect their taxonomic or threatened status (see O'Brien and Mayr 1991 for a variation on this theme). These lineages are threatened or endangered because of habitat alteration or destruction in many cases, and interbreeding may be a mechanism that allows these forms to respond to the altered environment. The hybrids produced will carry some of the genes of both parental forms and may give rise to new forms capable of surviving in altered habitats. If biodiversity is to have meaning, it is essential that we conserve the genes of endangered species rather than some abstract, Platonic phenotype recognized by classical taxonomy.

\section{ACKNOWLEDGMENTS}

We thank A. Kodric-Brown, J. Felsenstein, R. Harrison, W. Moore, D. Pennock, J.D. Rising, and S. Rohwer for comments on early versions and verbal presentations of the ideas contained in this manuscript.

\section{LITERATURE CITED}

ANDERSON, E. 1948. Hybridization of the habitat. Evol. 2:1-9.

ANDERSON, E. 1953. Introgressive hybridization. Biol. Rev. 28:280.

Anderson, E., ANd G. L. Stebrins, Jr. 1954. Hybridization as an evolutionary stimulus. Evol. 8:378-388.

ARNOLD, M. L. 1992. Natural hybridization as an evolutionary process. Ann. Rev. Ecol. Syst. 23: 237-261.

Barton, N. H. 1979. The dynamics of hybrid zones. Heredity 43:341-359.

Barton, N. H., and G. M. Hewttt. 1985. Analysis of hybrid zones. Ann. Rev. Ecol. Syst. 16:113148.

Barrowclough, G. F. 1980. Genotypic and phenotypic differentiation in a wood warbler hybrid zone. Auk 97:655-668.

Bell, D. 1992. Hybridization and sympatry in the Western Gull/Glaucous-winged Gull complex. Ph.D. diss., Univ. of California, Berkeley.

Bellrose, F. C. 1980. Ducks, geese, and swans of North America. Stackpole Press, Harrisburg, PA.

BLAIR, W. F. 1951. Interbreeding of natural populations of vertebrates. Am. Nat. 85:9-30.

Brodsky, L. M., AND P. J. WeatherheAd. 1984. Behavioral and ecological factors contributing to American Black Duck-Mallard hybridization. J. Wildl. Manage. 48:846-852.

Brodsky, L. M., P. J. Weatherhead, C. D. Ankney, AND D. G. DENNIS. 1988. The influence of male dominance on social interactions in black ducks and mallards. Anim. Behav. 36:1371-1378.

Bullini, L., AND G. NascetTI. 1990. Speciation by hybridization in phasmids and other insects. Can. J. Zool. 68:1747-1760.

BuRGER, J. 1981. On becoming independent in herring gulls: parent young conflict. Am. Nat. 117: 444-456.

CADE, T. J. 1983. Hybridization and gene exchange among birds in relation to conservation, p. 288309. In C. M. Schonewald-Cox, [ed.], Genetics and Conservation. Benjiman/Cummings, New York.

DoBzHANSKY, T. 1940. Speciation as a stage in evolutionary divergence. Am. Nat. 74:312-321. 
Grant, B. R., AND P. R. Grant. 1989. Evolutionary dynamics of a natural population. Univ. of Chicago Press, Chicago.

Grant, B. R., AND P. R. Grant. 1992. Hybridization of bird species. Science 256:193-197.

Grant, V. 1963. The origin of adapatations. Columbia Univ. Press, New York.

Gray, A. J., D. F. Marshall, and A. F. Raybould. 1991. A century of evolution in Spartina anglica. Adv. Ecol. Res. 21:1-62.

Harrison, R. G. 1991. Hybrid zones: windows on evolutionary processes. Oxford Reviews in Evol. Biol. 7:69-128.

Hoffman, W., J. A. Wiens, AND M. D. Scott. 1978. Hybridization between gulls (Larus glaucescens and L. occidentalis) in the Pacific Northwest. Auk 95: $441-458$.

Howell, T. H. 1952. Natural history and differentiation in the Yellow-bellied sapsucker. Condor 54:237-282.

HubBard, J. P. 1969. The relationships and evolution of the Dendroica coronata complex. Auk 86: $393-432$.

INGOLFSSON, A. 1987. Hybridization of glaucous and herring gulls in Iceland. Stud. Avian Biol. 10:131140.

JoHnston, R. F. 1969. Taxonomy of house sparrows and their allies in the Mediterranean Basin. Condor 71:129-139.

Kendeigh, C. 1952. Parental care and its evolution in birds. Ill. Biol. Monogr. 22:1-356.

KoDric-Brown, A. 1990. Mechanisms of sexual selection: insights from fishes. Ann. Zool. Fenn. 27: 87-100.

LACK, D. 1968. Ecological adaptations for breeding in birds. Methuen Press, London.

LACY, R. C. 1985. Evidence that group selection counters the evolution of sexual dimorphism. Evol. Theory 7:173-177.

LANDE, R. 1981. Models of speciation by sexual selection on polygenic traits. Proc. Nat. Acad. Sci., USA 78:3721-3725.

LANDE, R. 1982. Rapid origin of sexual isolation and character divergence in a cline. Evol. 36:213-223.

MCKINNEY, F. 1986. Ecological factors influencing the social systems of migratory dabbling ducks, $p$. 153-161. In D. I. Rubenstein and R. W. Wrangham [eds.], Ecological aspects of social evolution. Princeton Univ. Press, Princeton, NJ.

Manwell, C., C. M. ANN Baker, and W. Childers. 1962. Molecular genetics of hemoglobin in hybrid fishes and birds - a biochemical basis for heterosis. Fed. Proc. 21:267.

Manwell, C., C. M. Ann Baker, and W. Childers. 1963. The genetics of hemoglobin in hybrids $I$. A molecular basis for hybrid vigor. Comp. Biochem. and Physiol. 19:103-120.

MAYr, E. 1942. Systematics and the origin of species. Columbia Univ. Press, New York.

MAYR, E. 1963. Animal species and evolution. Belknap Press, Cambridge, MA.

Monaghan, P., and N. B. Metcalfe. 1986. On being the right size: natural selection and body size in the Herring Gull. Evol. 40:1096-1099.
Moore, W. S. 1977. An evaluation of narrow hybrid zones in vertebrates. Q. Rev. Biol. 52:263-277.

MoOre, W. S., AND D. B. Buchanan. 1985. Stability of the Northern Flicker hybrid zone in historical times: implications for adaptive speciation theory. Evol. 39:135-151.

MorRIs, R. D. 1986. Seasonal trends in "courtshipfeeding" rates of male Common Terns. Can. J. Zool. 64:501-507.

Morrison, M. L., AND J. W. HARdY. 1983. Hybridization between Hermit and Townsend's Warblers. Murrelet 64:65-72.

Nisbet, I.C.T. 1973. Courtship-feeding, egg-size, and breeding success in Common Terns. Nature 241: 141-142.

O'BrIEN, S., AND E. MAYR. 1991. Bureaucratic mischief: recognizing endangered species and subspecies. Science 251:1187-1188.

PANOv, E. N. 1989. Natural hybridization and ethological isolation in birds. M. Nauka Press, Moscow, USSR.

PATTEN, S. 1980. Interbreeding and Evolution in the Larus glaucescens- $L$. argentatus complex on the south coast of Alaska. Ph.D.diss., Johns Hopkins Univ., Baltimore, MD.

Picozzi, N. 1976. Hybridization of Carrion and Hooded Crows in northeastern Scotland. Ibis 118: 254-257.

Pierotti, R. 1981. Male female parental roles in Western Gulls under different environmental conditions. Auk 98:532-549.

Pierotti, R. 1987a. Isolating mechanisms in seabirds. Evolution 41:559-570.

PIERotti, R. 1987b. Behavioral consequences of habitat selection in the Herring Gull. Stud. Avian Biol. 10:119-128.

RATTENBURY, J. A. 1962. Cyclic hybridization as a survival mechanism in the New Zealand flora. Evol. 16:348-363.

Rising, J. D. 1970. Morphological variation and evolution in some North American orioles. Syst. Zool. 19:315-351.

Rising, J. D. 1983. The Great Plains hybrid zone. Current Ornithology 1:131-157.

Robiins, C. S., B. Bruhn, AND H. S. ZIM. 1983. Birds of North America. Golden Press, New York.

ShORT, L. L., JR. 1965. Hybridization in the flickers (Colaptes) of North America. Bull. Amer. Mus. Nat. Hist. 129:307-428.

SHORT, L. L., JR. 1969. Taxonomic aspects of avian hybridization. Auk 86:84-105.

Sibley, C. G. 1957. The evolutionary and taxonomic significance of sexual dimorphism and hybridization in birds. Condor 59:166-191.

Sibley, C. G., AND D. A. West. 1958. Hybridization in the red-eyed towhees of Mexico. Condor 60: 85-104.

Sibley, C. G., AND D. A. West. 1959. Hybridization in the rufous-sided towhees of the Great Plains. Auk 76:326-338.

Silver, R., H. ANDrews, and G. F. Ball. 1985. Parental care in an ecological perspective: a quantitative analysis of avian subfamilies. Amer. Zool. 25:823-840. 
Sмith, N. G. 1966. Evolution of some arctic gulls: an experimental study of isolating mechanisms. AOU Monographs 4:1-99.

VAURIE, C. 1954. Systematic notes on Palearctic birds no. 5, Corvidae. Amer. Mus. Novit. 1668:1-23.

VERNER, J., AND M. WILLSON. 1969. Mating systems, sexual dimorphism and the role of male North American passerine birds in the nesting cycle. AOU Monographs 9:1-76.

WAYNE, R. K., AND S. M. JeNkS. 1991. Mitochondrial DNA analysis implying extensive hybridization of the endangered red wolf Canis rufus. Nature 351: $565-568$.
WEST-Eberhard, M. J. 1983. Sexual selection, social competition, and speciation. Q. Rev. Biol. 58:155183.

Whitham, T. G., P. A. Morrow, and B. M. Potts. 1991. Conservation of hybrid plants. Science 248 : $779-780$.

Wilson, D. S., AND A. Hedrick. 1982. Speciation and the economics of mate choice. Evol. Theory $6: 15-24$

ZINK, R. M., AND J. V. REMSEN, JR. 1986. Evolutionary processes and patterns of geographic variation in birds. Curr. Ornithol. 4:1-69.

APPENDIX. List of avian families and subfamilies from which naturally occurring hybridization between species within a genus has been reported. Mating systems are listed as follows: (1) MM: monogamous and sexually monomorphc; (2) MD: monogamous and sexually dimorphic (includes polyandrous species); (3) PD: polygynous and sexually dimorphic. \#Species is the number of described species from each family or subfamily and \#Hybrid is the number of reported cross-species matings within a genus listed in Panov 1989. \%Hybrid = \#Hybrid/\#Species. Statistical analysis was conducted on log-transformed data using non-parametric KruskalWallis tests.

\begin{tabular}{|c|c|c|c|c|c|}
\hline Family & Subfamily & $\begin{array}{l}\text { Mating } \\
\text { system }\end{array}$ & \#Species & \#Hybrid & \%Hybrid \\
\hline \multicolumn{6}{|l|}{ Nonpasserines } \\
\hline Spheniscidae & & $\mathrm{MM}$ & 15 & 2 & 13 \\
\hline Gaviidae & & MM & 4 & 5 & 125 \\
\hline Podicipedidae & & MM & 18 & 8 & 44 \\
\hline Diomedeidac & & MM & 13 & 2 & 15 \\
\hline Procellariidae & & MM & 53 & 11 & 21 \\
\hline Sulidae & & MM & 7 & 2 & 29 \\
\hline Phalacrocoridae & & MM & 29 & 2 & 7 \\
\hline Ardeidae & & MM & 63 & 9 & 14 \\
\hline Threskiornithidae & & $\mathbf{M M}$ & 28 & 3 & 11 \\
\hline \multirow[t]{2}{*}{ Anatidae: } & Anserinae & MM & 45 & 26 & 58 \\
\hline & Anatinae & $\mathrm{MD}$ & 118 & 80 & 68 \\
\hline Falconidae & & MD & 57 & 7 & 12 \\
\hline \multirow[t]{3}{*}{ Accipitridae: } & Accipitrinae & MD & 40 & 9 & 23 \\
\hline & Buteoninae & $\mathbf{M M}$ & 40 & 4 & 10 \\
\hline & Milvinae & MM & 13 & 6 & 46 \\
\hline Megapodiidae & & MM & 10 & 2 & 20 \\
\hline Tetraonidae & & PD & 18 & 4 & 22 \\
\hline Phasianidae & & $\mathrm{PD}$ & 177 & 23 & 13 \\
\hline Gruidae & & MM & 14 & 6 & 43 \\
\hline Rallidae & & MM & 120 & 6 & 5 \\
\hline Otididae & & $\mathrm{PD}$ & 23 & 1 & 4 \\
\hline Jacanidae & & $\mathrm{MD}$ & 7 & 1 & 14 \\
\hline Haematopidae & & MM & 6 & 5 & 83 \\
\hline Charadriidae & & MM & 63 & 8 & 13 \\
\hline Scolopacidae & & $\mathbf{M M}$ & 42 & 4 & 10 \\
\hline Recurvirostridae & & MM & 7 & 2 & 29 \\
\hline Glareolidae & & MM & 16 & 2 & 13 \\
\hline Stercorariidae & & MM & 5 & 6 & 120 \\
\hline \multirow[t]{2}{*}{ Laridae: } & Larinae & MM & 43 & 40 & 93 \\
\hline & Sterninae & $\mathbf{M M}$ & 39 & 15 & 38 \\
\hline Alcidae & & $\mathbf{M M}$ & 21 & 2 & 10 \\
\hline Columbidae & & MM & 284 & 10 & 4 \\
\hline Psittacidae & & MM & 317 & 20 & 6 \\
\hline Cuculidae & & MM & 125 & 5 & 4 \\
\hline Strigidae & & MM & 121 & 3 & 3 \\
\hline Trochilidae & & $\mathrm{PD}$ & 319 & 23 & 7 \\
\hline Coliidae & & $\mathrm{MM}$ & 6 & 2 & 33 \\
\hline
\end{tabular}


APPENDIX. Continued.

\begin{tabular}{|c|c|c|c|c|c|}
\hline Family & Subfamily & $\begin{array}{l}\text { Mating } \\
\text { system }\end{array}$ & \#Species & \#Hybrid & \%Hybrid \\
\hline Alcedinidae & & MD & 86 & 4 & 5 \\
\hline Coraciidae & & MM & 11 & 6 & 55 \\
\hline Phoenoculidae & & $\mathbf{M M}$ & 6 & 2 & 33 \\
\hline Galbulidae & & MD & 15 & 2 & 13 \\
\hline Capitonidae & & MM & 72 & 8 & 11 \\
\hline Indicatoridae & & MD & 11 & 2 & 18 \\
\hline Ramphastidae & & MM & 37 & 4 & 11 \\
\hline \multirow[t]{2}{*}{ Picidae } & Jyginae & $\mathrm{MM}$ & 2 & 2 & 100 \\
\hline & Picinae & $\mathbf{M M}$ & 209 & 40 & 19 \\
\hline \multicolumn{6}{|l|}{ Passerines } \\
\hline Pipridae & & PD & 59 & 3 & 5 \\
\hline Tyrannidae & & MM & 367 & 19 & 5 \\
\hline Pittidae & & MD & 23 & 2 & 9 \\
\hline Alaudidae & & MM & 75 & 4 & 5 \\
\hline Hirundinidae & & MM & 79 & 3 & 4 \\
\hline Dricruridae & & MM & 20 & 2 & 10 \\
\hline Oriolidae & & MD & 28 & 4 & 14 \\
\hline Corvidae & & MM & 102 & 19 & 19 \\
\hline Cracticidae & & MM & 10 & 3 & 30 \\
\hline Paradisacidae & & PD & 40 & 5 & 13 \\
\hline Paridae & & MM & 46 & 32 & 70 \\
\hline Aegithalidae & & $\mathrm{MM}$ & 16 & 2 & 13 \\
\hline Remizidae & & MM & 2 & 2 & 100 \\
\hline Sittidae & & MM & 27 & 4 & 15 \\
\hline Certhiidae & & MM & 6 & 4 & 67 \\
\hline Mimidae & & MM & 10 & 2 & 20 \\
\hline Camphephagidae & & MM & 70 & 2 & 3 \\
\hline Pycnonotidae & & MM & 123 & 8 & 7 \\
\hline \multirow[t]{5}{*}{ Muscicapidae: } & Sylviinae & $\mathrm{MD}$ & 279 & 30 & 11 \\
\hline & Muscicapinae & MD & 398 & 16 & 4 \\
\hline & Turdinae & MD & 303 & 31 & 10 \\
\hline & Malurinae & MD & 83 & 11 & 13 \\
\hline & Timaliinae & $\mathbf{M M}$ & 257 & 10 & 4 \\
\hline Regulidae & & MD & 11 & 4 & 36 \\
\hline Motacillidae & & $\mathbf{M M}$ & 53 & 13 & 25 \\
\hline Artamidae & & MM & 10 & 2 & 20 \\
\hline Laniidae & & $\mathrm{MM}$ & 64 & 22 & 34 \\
\hline Meliphagidae & & MD & 168 & 6 & 4 \\
\hline Nectarinidae & & PD & 116 & 8 & 7 \\
\hline Dicacidae & & MD & 58 & 13 & 22 \\
\hline Zocteropidae & & $\mathrm{MM}$ & 90 & 4 & 4 \\
\hline Vireonidae & & $\mathrm{MM}$ & 37 & 2 & 5 \\
\hline \multirow[t]{9}{*}{ Emberizidae: } & Parulinae & MD & 115 & 20 & 17 \\
\hline & Emberizinae & MD & 259 & 27 & 10 \\
\hline & & MM & 15 & 9 & 60 \\
\hline & Icterinae & $\mathrm{PD}$ & 86 & 6 & 7 \\
\hline & Sturnella & MM & 2 & 2 & 100 \\
\hline & Thraupinae & MD & 214 & 19 & 9 \\
\hline & Caerobinae & MD & 40 & 6 & 15 \\
\hline & Geospizinae & $\mathrm{MM}$ & 12 & 14 & 117 \\
\hline & Cardinalinae & $\mathrm{MD}$ & 40 & 7 & 18 \\
\hline \multirow[t]{2}{*}{ Ploecidae: } & Passerinae & $\mathrm{MD}$ & 27 & 15 & 56 \\
\hline & Ploecinae & MD & 104 & 2 & 2 \\
\hline \multirow[t]{2}{*}{ Estrildidae: } & Estrildinae & MD & 107 & 9 & 7 \\
\hline & Viduinae & $\mathrm{PD}$ & 9 & 8 & 89 \\
\hline
\end{tabular}

Hybrid Data from Panov, E. N. 1989. Natural hybridization and ethological isolation in birds. Nauka Press, Moscow. Hybrid Data from PaNOv, E. N. 1989. Natural hybridization and ethological isolation in birds. Nauka Press, Moscow.
birds. Golden Press, New York. 